\title{
KEY PARAMETERS FOR THE ANALYSIS STAGE OF INTERNATIONALIZATION OF OPERATIONS ${ }^{1}$
}

1 This research has been funded by the Spanish Ministry of Science and Education project, entitled 'Operations Design and Management in Global Supply Chains (GLOBOP)' (Ref. DPI2012-38061-C02-01).

\section{Hanzel Grillo}

hangries@upvnet.upv.es

\section{Josefa Mula}

fmula@cigip.upv.es

\section{Sandra Martínez}

sandra.martinez@globope.es

\section{Ander Errasti}

aerrasti@tecnun.es

\begin{abstract}
In this paper, we identify the key parameters to consider in a decision model on internationalization of operations. In order to propose these parameters, the GLOBOPE framework was adopted as the basis of this work. This framework contemplates the three commonest challenges of global operations configuration for industrial manufacturing companies in an internationalization process, which are: new facility implementation (NFI); global suppliers' network development (GSND); multisite production network configuration. A set of suitable parameters is herein provided for NFI and GSND in the analysis stage from strategic, tactical and operational decision levels. These parameters could be used in the future as a basis for the development of quantitative tools for decision making on the internationalization of operations.
\end{abstract}

Keywords: Internationalization of operations; key parameters; new facility implementation; global suppliers' network development; analysis stage. 


\section{INTRODUCTION}

Martinez (2013) defines internationalization of operations as the deployment of business resources all over the country by locating people and assets to execute primary activities of the value chain. Researchers and professionals have shown a relatively dispersed interest in internationalization of operations.

This study is based, mainly, on the works of Errasti (2011), Martinez (2013) and Martínez et al. (2013), which summarise the main contributions made by researchers from the field of internationalization of operations processes as regards principles, tools and techniques to support managers and professionals in the analysis, design and management process of a global production and logistics network. These contributions are summarised within the framework known as Global Operations (GLOBOPE), which is divided into three main parts: new facility implementation (NFI), global suppliers' network development (GSND) and multisite production network configuration (MPNC). The development and implementation of NFI, GNSD and MPNC is structured through the subdivision into stages, analysis, set up, stability, improvement and excellence.

In this paper, the focus is on the analysis stage of NFI and GSND types. The aim is to explore different indicators that could be used in the analysis stage in order to evaluate the suitability for an enterprise or supply chain in the decision making process of internationalizing their operations. The main objective is to identify those indicators in order to set them as a basis for future research directed to develop mathematical analysis and modelling for decision supporting in this area. A revision of each of the references mentioned by Martinez (2013) is being synthesized in the analysis stage for $\mathrm{NFI}$ and GSND, where specific indicators are sought for. The main contributions of this paper are to present the resulting set of the main key parameters to consider in the analysis stage of the NFI for strategic, tactical and operational decision levels and GSDN for tactical and operational decision levels.

The rest of the paper is arranged as follows. Section 2 introduces a brief description of related works; meanwhile section 3 presents a quick general introduction of the GLOBOPE framework. Section 4 presents the resulting set of indicators obtained after the literature revision. Section 5 presents a discussion over the set of indicators proposed and, finally, section 6 provides the conclusions.

\section{RELATED WORKS}

The scientific literature includes a variety of studies that mainly analyse case studies of companies that have had to extend their operations, of either the production or services type, to other frontiers. Andersen (1997) revises theories and conceptual models to establish the supply chain, transaction costs and organizational capacity to enter new markets; it has been established that there is a lack of coherence between theory and the operational level. Coviello et McAuley (1999) review empirical research works conducted into the internationalization of small companies in a direct foreign investment context. They identify standards in several dimensions in the various cases they analyse, such as characteristics, methods used, etc. Prasad et Babbar (2000) examine the literature on the structure of internationalization of operations, where a tendency of delimiting the region or country where companies are located, level of industrialisation, etc., is identified in the research works. Etemad (2004) reviews theoretical frameworks that refer to internationalization of small and medium enterprises (SMEs), the characteristics that lead companies to undertake internationalization, and the pros and cons of this process compared to large firms. Sommer et Troxler (2007) analyse outsourcing and offshoring processes from a more empirical perspective by conducting interviews and making evaluations with consultants from several companies who have undertaken both processes. They stress the advantages, risks and impact of the occupational situation in saturated markets. De Toni et Parussini (2010) review the scientific literature on the origins and evolution of the international production network. Other studies focus on a more profound analysis of the specific areas or processes in developing internationalization. Initially by analysing the internationalization of four Swedish companies, Johanson et Wiedersheim (1975) describe the process that has allowed them to reach their current international position. Johanson et Vahlne (1977) develop an internationalization process model of a company that focuses on gradual acquisition, integration and use of knowledge in terms of overseas markets and their growing commitment with the company. Johanson et Vahlne (1990) describe the internationalization mechanism based on the previous model. Dawson (1994) explains the need for the theoretical explanations of existing frameworks in the internationalization of operations-related cost paradigm not having so many differences between some companies and others; this work analyses the specific retail case of the internationalization of operations. Eriksson et al. (1997) analyse the relationship between lack of knowledge on markets, businesses and foreign institutions and the subsequent internationalization process cost. More recent studies present the first theoretical essays to qualitatively and quantitatively analyse the decision made to internationalize. Hammami et al. (2008) determine the importance of characteristics such as cost, constraints and decisions in the delocation process problems that must be included in the supply chain's design models. Kedia et Mukherjee (2009) present an analytical framework with the reasons why companies 
subcontract processes or services in global markets. Aspelund et Butsko (2010) examine decisions made by SMEs to subcontract production operations to low-cost countries, including motivation, location, etc.; they also study the relationship between decisions and subsequent international market expansion. Mediavilla et al. (2012) explore the application of the model of Ferdows (1997) to make good use of overseas plants, which they include in their analysis of the strategic role in global operations networks to extend the scope of the model by applying a road map to gradually improve the plant's role in the global market. Armengol et al. (2014) propose a conceptual model for a representative cost structure associated with the internationalization of operations.

Other similar studies from the existing wide variety could be cited; however, most of them describe the internationalization processes, and do not specifically analyse the evaluation and relevance of the decision to internationalize in depth. Thus, we have based our investigation in the GLOBOPE framework, by going directly to the proposed literature in the analysis stage of NFI and GSND. The objective of this paper is to set up an initial set of measures that, quantitatively, provides the elements needed to develop a decisional model for the analysis of the pertinence of internationalization of operations.

\section{RESEARCH METHODOLOGY}

Errasti (2011) defines GLOBOPE as a framework for the design and configuration process of a global production and logistic network that can be a useful management tool for SMEs, strategic business units (SBUs) and steering committees that are responsible for making global operations effective and efficient. According to Martínez et al. (2013), GLOBOPE bears in mind the key decisions of the operations' strategy that need to be made about a global production and logistic network configuration and design in the internationalization process. The framework considers three core challenges relating to operations configuration: NFI, GSND and multisite production network configuration. All the previous problems must be dealt with according to five main stages: analysis, set up, stability, improvement, and excellence. In this paper, based on the proposal of principles, methods and tools to aid during the decision-making process for the analysis stage of NFI and GSND by Martínez et al. (2013), we review the scientific literature related to these principles, methods and tools for the analysis stage in order to identify the key quantitative parameters that allow the detailed evaluation of strategic, tactical and operational key decisions for NFI and tactical and operational key decisions for GSND that must be made before devising the internationalization plan.

\section{KEY PARAMETERS FOR THE GLOBOPE-BASED ANALYSIS STAGE}

Martinez (2013) proposes different principles, methods and tools to evaluate the key internationalization of operations' decisions made in the analysis stage. Here we reviewed all these principles, methods and tools, as well as the reference literature proposed. Several parameters were identified, which can be quantifiable to evaluate each key decision. The objective is to obtain an initial basis of the evaluation parameters for the internationalization of operations process analysis. These parameters could, a posteriori, be interpreted using mathematical programming models, analytical formulations or simulation models based on system dynamics. Tables 1, 2 and 3 provide the results of the review conducted, which was based on Martinez's initial proposal (2013). Key decisions and bibliographic sources according to the GLOBOPE framework were included, and the key parameters, which were identified to evaluate the key decision for both NFI and GSDN, were also directly included.

Table 1. Key parameters for the analysis stage. $\mathrm{NFI}$ strategic decisions

\begin{tabular}{|c|c|}
\hline $\begin{array}{c}\text { Key decisions/ } \\
\text { sources }\end{array}$ & Key parameters \\
\hline $\begin{array}{c}\text { Manufacturing } \\
\text { facility location } \\
\text { (MacCarthy and } \\
\text { Atthirawong, } \\
\text { 2003; Abele et al. } \\
\text { 2008) }\end{array}$ & $\begin{array}{c}* \text { Cost per square meter of construction } \\
* \text { Land cost } \\
* \text { Technology cost } \\
* \text { Government restrictions cost } \\
* \text { Total production cost } \\
* \text { Total transport cost } \\
* \text { Capital cost } \\
* \text { Material cost } \\
* \text { Labour productivity } \\
* \text { Capital productivity } \\
* \text { Distance from relevant markets } \\
* \text { Freight rates } \\
\text { * Potential restructuring and closure costs }\end{array}$ \\
\hline $\begin{array}{l}\text { Facility strategic } \\
\text { role (Ferdows, } \\
\text { 1997) }\end{array}$ & $\begin{array}{c}* \text { Availability of subsidies } \\
* \text { Access to low-cost production } \\
* \text { Qualified and specialised personnel } \\
* \text { Market proximity }\end{array}$ \\
\hline $\begin{array}{c}\text { Integration or } \\
\text { fragmentation } \\
\text { of productive } \\
\text { and logistics } \\
\text { operations: Make } \\
\text { or buy decisions } \\
\text { (Fine et al. 2002; } \\
\text { Abele et al. 2008) }\end{array}$ & $\begin{array}{c}* \text { Economic value added } \\
* \text { Total costs } \\
* \text { Assets } \\
* \text { Revenues } \\
* \text { Competitive cost structure } \\
* \text { Strategic value added } \\
* \text { Customer importance } \\
* \text { Technology clock speed } \\
* \text { Competitive position } \\
* \text { Capable suppliers } \\
* \text { Architecture } \\
* \text { Procurement cost }\end{array}$ \\
\hline
\end{tabular}


Brazilian Journal of Operations \& Production Management

Volume 15, Número 2, 2018, pp. 173-181

DOI: 10.14488/BJOPM.2018.v15.n2.a1

\begin{tabular}{|c|c|}
\hline $\begin{array}{l}\text { Service delivery } \\
\text { strategy } \\
\text { - Supply strategy } \\
\text { (Poler et al. } \\
\text { 2002) }\end{array}$ & $\begin{array}{l}\text { * Quality in information or decisions } \\
\text { * Strategic quality factor of human resources } \\
\text { * Tactic quality factor of human resources } \\
\text { * Operational quality factor of human } \\
\text { resources } \\
\text { * Yearly cost per human resources } \\
\text { * Interruptions in decision making } \\
\text { * Total quality of the decision system }\end{array}$ \\
\hline $\begin{array}{l}\text { - Manufacturing } \\
\text { strategy (Milten- } \\
\text { burg 2009, 2005; } \\
\text { Martinez, 2013) }\end{array}$ & $\begin{array}{c}\text { * Currency cost savings } \\
* \text { Logistic costs by geographic area } \\
* \text { Local production cost } \\
* \text { Material cost } \\
* \text { Labor cost } \\
* \text { Overhead cost } \\
* \text { Other production costs } \\
* \text { Product quality } \\
* \text { Delivery time } \\
* \text { Flexibility } \\
* \text { Innovativeness } \\
* \text { Accessibility } \\
* \text { Effectiveness of learning curves } \\
* \text { Learning } \\
* \text { Cost savings due to offshore factories } \\
* \text { Mobility } \\
* \text { Reliability in due date achieving } \\
* \text { Thriftiness }\end{array}$ \\
\hline $\begin{array}{c}\text { - Purchasing } \\
\text { strategy (Traut- } \\
\text { mann et al. 2009; } \\
\text { Gelderman et } \\
\text { Semeijn, 2006) }\end{array}$ & $\begin{array}{c}\text { * Activity of competence } \\
* \text { Relevant supply market } \\
* \text { Purchase difficulty } \\
* \text { Purchase complexity } \\
* \text { Supplier performance } \\
* \text { Strategic partnership } \\
* \text { Ordering cost } \\
* \text { Supply assurance } \\
\text { * Dominant suppliers' conditions } \\
* \text { Safety stocks } \\
\text { * Knowledge and volume of purchases } \\
\text { * Flexibility } \\
\text { * Added value of purchased product } \\
* \text { e-procurement } \\
\text { * Degree of aggregation of purchases } \\
* \text { Cost savings } \\
\text { * Profitability of the final product purchase } \\
* \text { Supply risk }\end{array}$ \\
\hline $\begin{array}{c}\text { Global Opera- } \\
\text { tions Network } \\
\text { - Distribution } \\
\text { network } \\
\text { (Abele et al. } \\
\text { 2008; Waters, } \\
\text { 2003) }\end{array}$ & $\begin{array}{c}* \text { Technology cost } \\
* \text { Government restrictions cost } \\
* \text { Total production cost } \\
* \text { Total transport cost } \\
* \text { Material cost } \\
* \text { Distance from relevant markets } \\
* \text { Freight rates } \\
\text { * Potential restructuring and closure costs }\end{array}$ \\
\hline
\end{tabular}

\begin{tabular}{|c|c|}
\hline $\begin{array}{c}\text { - Manufacturing } \\
\text { network } \\
\text { (Martinez, 2013) }\end{array}$ & $\begin{array}{c}* \text { Manufacturing network type } \\
* \text { Innovativeness } \\
* \text { Local production cost } \\
* \text { Material cost } \\
* \text { Other production costs } \\
* \text { Overhead cost } \\
* \text { Logistic costs per geographic area } \\
* \text { Labor cost } \\
\text { * Scope of the manufacturing network } \\
* \text { Delivery time } \\
\text { * Cost savings due to offshore factories } \\
* \text { Product quality } \\
* \text { Delivery reliability in due date achieving } \\
* \text { Flexibility }\end{array}$ \\
\hline $\begin{array}{l}\text { - Suppliers net- } \\
\text { work } \\
\text { (Meixell et } \\
\text { Gargeya, 2005; } \\
\text { Kraljic, 1983) }\end{array}$ & 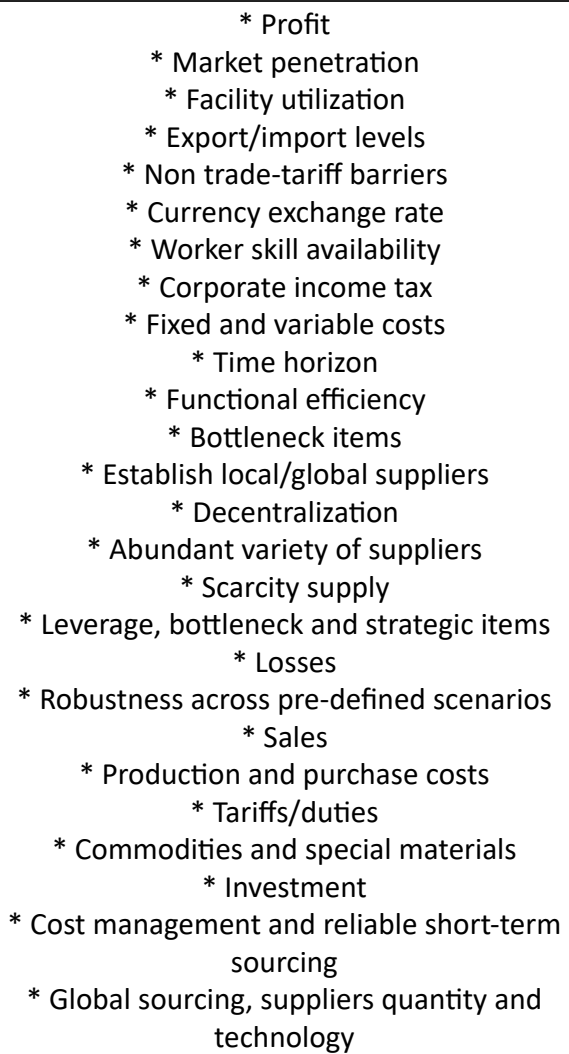 \\
\hline
\end{tabular}

Table 2. Key parameters for the analysis stage. NFI tactical and operational decisions

\begin{tabular}{|c|c|}
\hline $\begin{array}{c}\text { Key decisions/ } \\
\text { sources }\end{array}$ & Key parameters \\
\hline $\begin{array}{c}\text { Plant and factory con- } \\
\text { struction or adapta- } \\
\text { tion (Martinez, 2013) }\end{array}$ & $*$ Greenfield: New facilities from the \\
ground \\
Brownfield: Acquisition of existing \\
resources
\end{tabular}




\begin{tabular}{|c|c|}
\hline $\begin{array}{l}\text { Technological level } \\
\text { of the facility and } \\
\text { automation level of } \\
\text { the process } \\
\text { (Ferdows, 1997; Corti } \\
\text { et al. 2009) }\end{array}$ & $\begin{array}{c}\text { * Availability of subsidies } \\
* \text { Labour force characteristics } \\
* \text { Infrastructure } \\
* \text { Proximity to suppliers } \\
* \text { Competitors activity } \\
* \text { Quality of life } \\
* \text { Legal context } \\
* \text { Macroeconomic factors } \\
* \text { Political factors } \\
* \text { Local managers availability } \\
* \text { Access to low-cost production } \\
* \text { Training facility } \\
* \text { Proximity to markets/customers } \\
* \text { Costs } \\
\text { * Proximity to headquarters } \\
* \text { Site competence } \\
\text { * Availability of qualified and specialized } \\
\text { human resources }\end{array}$ \\
\hline $\begin{array}{c}\text { Facility material flow } \\
\text { design and planning } \\
\text { process } \\
\text { (Errasti, 2006; Muther } \\
\text { et al. 1981; Tompkins, } \\
\text { 2010) }\end{array}$ & 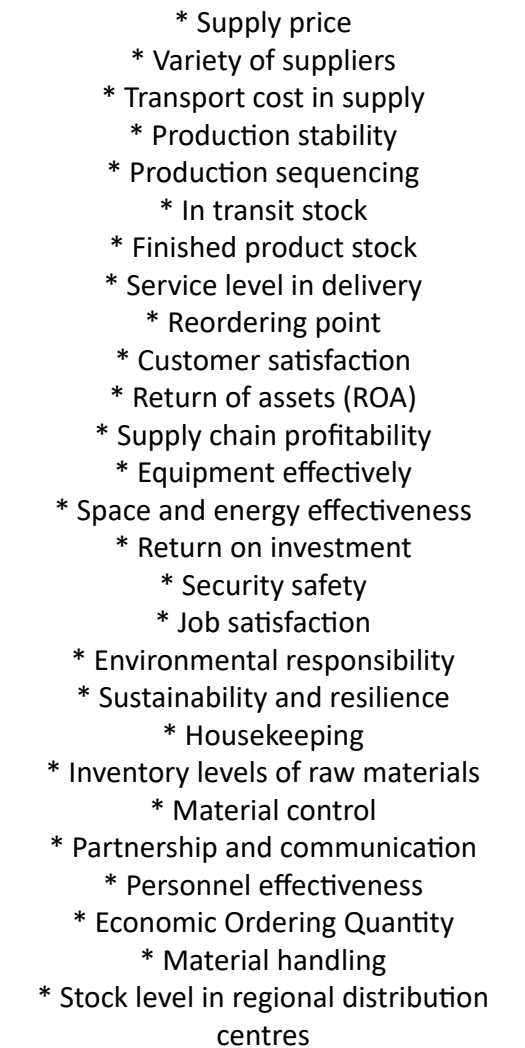 \\
\hline
\end{tabular}

\begin{tabular}{|c|c|}
\hline $\begin{array}{l}\text { Facility layout design } \\
\text { (Muther et al. 1981; } \\
\text { Hayes et Wheel- } \\
\text { wright, 1984; } \\
\text { Lluís, 2009) }\end{array}$ & 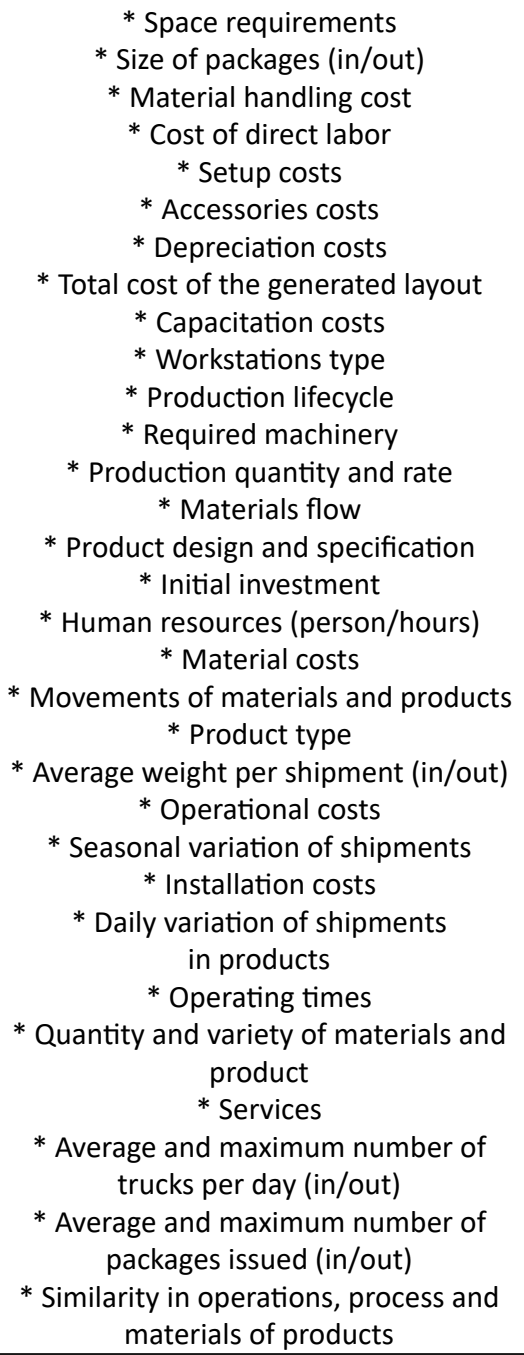 \\
\hline $\begin{array}{l}\text { Areas and workstation } \\
\text { detailed design } \\
\text { (Lluís, 2009) }\end{array}$ & $\begin{array}{l}* \text { Amount of required equipment } \\
* \text { Required surface } \\
* \text { Distribution of equipment and work- } \\
\text { stations }\end{array}$ \\
\hline $\begin{array}{l}\text { Procurement, distri- } \\
\text { bution, installation } \\
\text { and location of equip- } \\
\text { ment and machines } \\
\text { (Knoepfel, 1983) }\end{array}$ & $\begin{array}{c}* \text { Total income } \\
* \text { Land cost } \\
* \text { Depreciation } \\
* \text { Interest rate } \\
\text { * Operations' expense } \\
\text { * Salaries } \\
* \text { Total profit } \\
* \text { Risk level }\end{array}$ \\
\hline
\end{tabular}




\begin{tabular}{|c|c|}
\hline $\begin{array}{l}\text { Procurement tools } \\
\text { and jigs } \\
\text { (Yurdakul, 2004) }\end{array}$ & 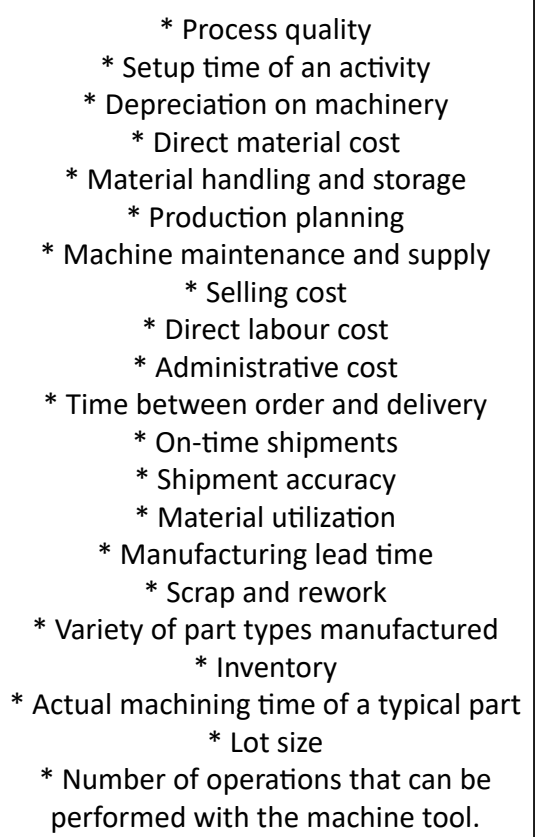 \\
\hline $\begin{array}{l}\text { Shop floor manage- } \\
\text { ment design } \\
\text { (Szulanski, 1996) }\end{array}$ & $\begin{array}{l}\text { * Eventfulness of knowledge transfer } \\
\text { * Degree to which the donor of the best } \\
\text { practice is perceived as reliable } \\
\text { * Degree to which the organizational } \\
\text { context supports the development of } \\
\text { transfers. }\end{array}$ \\
\hline
\end{tabular}

Table 3. Key parameters for the analysis stage. GSND decisions

\begin{tabular}{|c|c|}
\hline $\begin{array}{c}\text { Key decisions/ } \\
\text { sources }\end{array}$ & Key parameters \\
\hline $\begin{array}{c}\text { Link between business } \\
\text { and purchasing } \\
\text { strategy }\end{array}$ & $*$ Location \\
(Slack et Lewis, 2002) & $*$ Organizational structure \\
& $*$ Suppliers \\
& * Responsiveness in time, volume, vari- \\
& ety flexibility, cost. \\
\hline & $*$ Economic value added \\
& $*$ Total costs \\
Make or buy & $*$ Revents \\
(Fine et al. 2002) & $*$ Competitive cost structure \\
& $*$ Capable suppliers \\
& $*$ Customer importance \\
& $*$ Strategic value added \\
& $*$ Technology clock speed \\
& $*$ Architecture \\
& $*$ Competitive position \\
\hline
\end{tabular}

\begin{tabular}{|c|c|}
\hline $\begin{array}{l}\text { What and whom to } \\
\text { buy? } \\
\text { (Kraljic, 1983; Marti- } \\
\text { nez, 2013) }\end{array}$ & $\begin{array}{c}\text { * Functional efficiency } \\
* \text { Bottleneck items } \\
* \text { Establish local/global suppliers } \\
* \text { Decentralization } \\
* \text { Abundant variety of suppliers } \\
* \text { Scarcity supply } \\
\text { * Commodities and special materials } \\
* \text { Time horizon } \\
\text { * Leverage, bottleneck and strategic } \\
\text { items } \\
\text { * Cost management and reliable short- } \\
\text { term sourcing } \\
\text { * Global sourcing, suppliers quantity } \\
\text { and technology }\end{array}$ \\
\hline $\begin{array}{l}\text { Purchase policy for } \\
\text { each category } \\
\text { (Sarkar et Mohapatra, } \\
\text { 2006; Kauffman et } \\
\text { Leszczyc, 2005) }\end{array}$ & 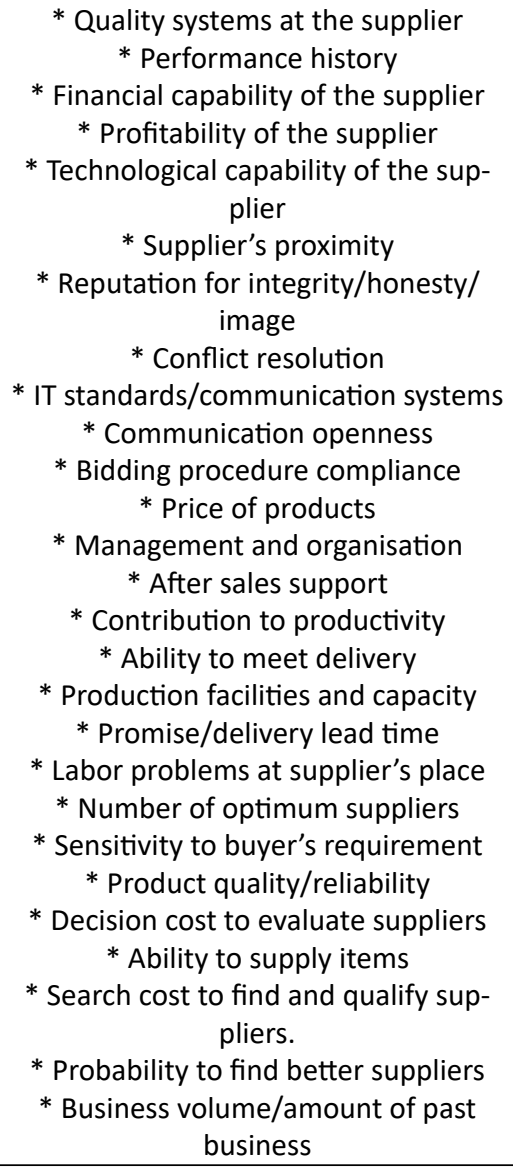 \\
\hline $\begin{array}{l}\text { Supplier selection } \\
\text { process } \\
\text { (Al-Harbi,1998) }\end{array}$ & $\begin{array}{c}* \text { Contractor`s new fee } \\
* \text { Total profit of the project } \\
* \text { Total Cost } \\
* \text { Expected utility value (EUV) }\end{array}$ \\
\hline
\end{tabular}




\begin{tabular}{|c|c|}
\hline $\begin{array}{l}\text { Contract management } \\
\text { (Al-Harbi, 1998; Turn- } \\
\text { er and Simister, 2001; } \\
\quad \text { Holt, 1998) }\end{array}$ & $\begin{array}{l}\text { * Cost of changes in product specifica- } \\
\text { tion } \\
* \text { Total cost } \\
\text { * Variations cost of the process specifi- } \\
\text { cation } \\
\text { * Price of contract } \\
* \text { Aggregate score for contractor } \\
* \text { Uncertainty in the product } \\
* \text { Euclidean distances of clusters } \\
* \text { Uncertainty in the process } \\
* \text { Multiple Regression of variables } \\
* \text { Total profit of the project } \\
\text { * Membership functions for uncertainty } \\
* \text { Contractor's new fee } \\
\text { * Predictive contractor performance } \\
* \text { Expected utility value } \\
\text { * Cost of product specification in the } \\
\text { tender documentation } \\
\text { * Cost specification of the working } \\
\text { methods in supply documentation }\end{array}$ \\
\hline $\begin{array}{l}\text { Purchasing strategic } \\
\text { objectives for product } \\
\text { category (Martinez, } \\
\text { 2013) }\end{array}$ & $\begin{array}{c}* \text { Quality of products } \\
* \text { Productivity cost } \\
\text { * Delivery exactness } \\
\text { * Security } \\
* \text { Moral } \\
\text { * Product type } \\
\text { * Acquisition per volume }\end{array}$ \\
\hline $\begin{array}{l}\text { Procurement strategy } \\
\text { (Martinez, 2013) }\end{array}$ & $\begin{array}{c}\text { * Supply characteristics } \\
* \text { Demand characteristics } \\
* \text { Raw materials characteristics } \\
\text { * Material requirement planning (MRP) }\end{array}$ \\
\hline
\end{tabular}

\section{DISCUSSION}

Table 1, Table 2 and Table 3 show the resulting set list of KPI identified in the literature referenced in the analysis stage for NFI and GSND. We have identified several indicators for each decisional level, and inside of each decisional level, for each specific key decision. Now, we have found that, many of the indicators are participating, simultaneously, in several key decisions along of NFI and GSND. This fact means that, the list could be refined by identifying all these relationships among indicators with the key decisions they could support. Due to that, in order to set a initial basic list of KPIs to develop decisional mathematical models, a refining steps must be conducted to eliminate redundant information by considering that one same KPI could contribute to multiple key decisions. Then, the resulting list of this work is a valuable starting point because it states a global set of information, containing all the main parameters to be taken into account.

It is important to highlight that in the set of the indicators identified, some of them could be modelled and, mathematically, formulated but in other cases, these indicators seem to be rather linguistic variables. In this case, the use of fuzzy
TOPSIS tools could be useful in order to complement quantitative mathematical models with other qualitative variables or models. Future research steps must be oriented to structure, summarise and formulate them.

\section{CONCLUSIONS}

This work reviewed the GLOBOPE framework as a suitable means to analyse the internationalization of operations process because the literature on this matter is disperse. This analysis was carried out specifically in the analysis stage of the GLOBOPE model. Here, key decisions were evaluated before implementing and setting up the internationalization of operations process. Then, an analysis of the literature review related to the principles, methods and tools for the decision-making process of these key decisions was done in order to identify and propose a set of key parameters. These key parameters can be employed as a basis to quantitatively evaluate these key decisions. Tables 1, 2 and 3 summarise the possible parameters for each GLOBOPE framework, NFI and GNSD possibility, along with their strategic, tactical and operational decisions. This series of parameters must act as a basis for future research lines in which the most relevant decisions are identified, and duplicities are refined and eliminated to comprehensively measure each decision. This is done to establish future mathematical or dynamical evaluation models based on empirical or historical data of standards, and on information about the company interested in being internationalized, in order to objectively determine the quantitative criteria of the relevance, or not, of extending operations to other latitudes.

\section{REFERENCES}

Abele, E. et al. (2008), Global Production: A Handbook for Strategy and Implementation, Berlin-Heidelberg.

Al-Harbi, K. M. A. S. (1998), "Sharing fractions in cost-plus-incentive-fee contracts", International Journal of Project Management, Vol. 16, pp. 73-80.

Andersen, O. (1997), "Internationalization and market entry mode: A review of theories and conceptual frameworks", Management International Review, pp. 27-42.

Armengol, A. et al. (2014), "Conceptual model for associated costs of the internationalisation of operations", Lecture Notes in Engineering and Computer Science, Vol. 3, pp. 18188.

Aspelund, A.; Butsko, V. (2010), "Small and Middle-Sized Enterprises' Offshoring Production: A Study of Firm Decisions and Consequences", Tijdschrift voor Economische en Sociale Geografie, Vol. 101, pp. 262-75.

Corti, D. et al. (2009), "Challenges for off-shored opera- 
Brazilian Journal of Operations \& Production Management

Volume 15, Número 2, 2018, pp. 173-181

DOI: 10.14488/BJOPM.2018.v15.n2.a1 tions: findings from a comparative multi-case study analysis of Italian and Spanish companies", in: Proceedings 16th Annual EurOMA Conference, Gothenburg, 2009.

Coviello, N. E.; McAuley, A. (1999), “Internationalisation and the smaller firm: A review of contemporary empirical research", Management International Review, pp. 223-56.

Dawson, J.A. (1994), "Internationalization of retailing operations", Journal of Marketing Management, Vol. 10, pp. 267-82.

De Toni, A.; Parussini, M. (2010), "International Manufacturing Networks: a literature review", in: 17th Conference EurOMA, Porto, Portugal, 2010.

Eriksson, K. et al. (1997), "Experiential knowledge and cost in the internationalization process", Journal of International Business Studies, pp. 337-60.

Errasti, A. (2006), KATAIA. Modelo para el diagnóstico y despliegue de la estrategia logística y productiva en Pymes y unidades de negocio de grandes empresas. PhD thesis in Economic Sciences, University of Navarra, Tecnun, San Sebastian, Spain.

Errasti, A. (2011), "International manufacturing networks: Global operations design and management. Servicio de Publicaciones del Gobierno Vasco", in: Eusko Jaurlaritzaren.

Etemad, H. (2004), "Internationalization of small and medium-sized enterprises: a grounded theoretical framework and an overview", Canadian Journal of Administrative Sciences, Vol. 21, 1-21.

Ferdows, K. (1997), "Making the most of foreign factories", Harvard Business Review Vol. 75, 73-91.

Fine, C. H. (2002), "Rapid response capability in value chain design", Sloan Management Review.

Gelderman, C. J.; Semeijn, J. (2006), "Managing the global supply base through purchasing portfolio management", Journal of Purchasing and Supply Management, Vol. 12, pp. 209-17.

Hammami, R. et al. (2008), "Supply chain design in the delocalization context: Relevant features and new modeling tendencies", International Journal of Production Economics, Vol. 113, 641-56.

Hayes, R. H.; Wheelwright, S.C. (1984), Restoring our competitive edge: competing through manufacturing, 1st ed., Wiley, Nova Jersey.

Holt, G. D. (1998), "Which contractor selection methodology?", International Journal of Project Management, Vol. 16, pp. 153-64.

Johanson, J.; Vahlne, J. E. (1977), “The internationalization process of the firm-a model of knowledge development and increasing foreign market commitments", Journal of International Business Studies, pp. 23-32.
Johanson, J.; Vahlne, J.E. (1990), "The mechanism of internationalisation", International Marketing Review, Vol. 7.

Johanson, J.; Wiedersheim-Paul, F. (1975), "The internationalization of the firm-four swedish cases 1", Journal of Management Studies, Vol. 12, 305-23.

Kauffman, R. G.; Leszczyc, P. T. P. (2005), “An optimization approach to business buyer choice sets: How many suppliers should be included?", Industrial Marketing Management Journal, Vol. 34, 3-12.

Kedia, B. L., Mukherjee, D. (2009), “Understanding offshoring: A research framework based on disintegration, location and externalization advantages", Journal of World Business, Vol. 44, 250-61.

Knoepfel, H. (1983), "Systematic project management”, International Journal of Project Management, Vol. 1, 234-41.

Kraljic, P. (1983), "Purchasing must become supply management", Harvard Business Review, Vol. 61, 109-17.

Lluís, C. (2009), "Diseño avanzado de procesos y plantas de producción flexible", Profit Editorial, pp. 77-78.

MacCarthy, B. L.; Atthirawong, W. (2003), "Factors affecting location decisions in international operations - a Delphi study", International Journal of Operations \& Production Management, Vol. 23, 794-18.

Martinez, S. (2013), Framework for configuring production and logistics networks of SMEs and SBUs within an internationalization process, Dissertation, Universidad de Navarra, San Sebastián, País Vasco.

Martínez, S. et al. (2013), "Framework for Improving the Design and Configuration Process of Global Operations", in: Advances in Production Management Systems. Competitive Manufacturing for Innovative Products and Services, Springer, New York, pp. 471 -78.

Mediavilla, M. et al. (2012), "Value Chain Based Framework for Assessing the Ferdows' Strategic Plant Role: An Empirical Study", in: Advances in Production Management Systems. Value Networks: Innovation, Technologies, and Management, Springer, New York, pp. 369-78.

Meixell, M. J.; Gargeya, V. B. (2005), "Global supply chain design: A literature review and critique", Global Logistic, Vol. 41, 531-50.

Miltenburg, J. (2005), Manufacturing strategy: how to formulate and implement a winning plan, 2 nd ed., John Wiley \& Sons, New Jersey.

Miltenburg, J. (2009), "Setting manufacturing strategy for a company's international manufacturing network", International Journal of Production Research, Vol. 47, 6179-203.

Muther, R. et al. (1981), Distribución en planta, Hispano Europea, Barcelona. 
Poler, R. et al. (2002), "Dynamic modelling of decision systems (DMDS)", Computers in Industry, Vol. 49, 175-93.

Prasad, S.; Babbar, S. (2000), "International operations management research", Journal of Operations Management, Vol. 18, 209-47.

Sarkar, A.; Mohapatra, P. K. (2006), "Evaluation of supplier capability and performance: A method for supply base reduction", Journal of Purchasing \& Supply Management, Vol. 12, 148-63.

Slack, N.; Lewis, M. (2002), Operations Strategy, 2nd ed., Prentice Hall, New Jersey.

Sommer, C.; Troxler, G. (2007), "Outsourcing and Offshoring: The Consultancies' Estimates", in: Software Engineering Approaches for Offshore and Outsourced Development, Springer, New York, pp. 109-13.

Szulanski, G. (1996), "Exploring internal stickiness: Impediments to the transfer of best practice within the firm", Strategic Management Journal, Vol. 17, 27-43.
Tompkins, J. A. (2010), Facilities planning, John Wiley \& Sons, New Jersey.

Trautmann, G. et al. (2009), "Global sourcing in integrated network structures: The case of hybrid purchasing organizations", Journal of International Management, Vol.15, 194-08.

Turner, J. R.; Simister, S. J. (2001), “Project contract management and a theory of organization", International Journal of Project Management, Vol. 19, 457-64.

Waters, C. D. J. (2003), Global logistics and distribution planning: strategies for management, Kogan Page Publishers, London.

Yurdakul, M. (2004), "AHP as a strategic decision-making tool to justify machine tool selection", Journal of Materials Processing Technology, Vol. 146, 365-76.

Received: 11 Sept 2016

Approved: 08 May 2018

DOI: 10.14488/BJOPM.2018.v15.n2.a1

How to cite: Grillo, H., Mula, J., Martínez, S. et al. (2018), "Key Parameters for the Analysis Stage of Internationalization of Operations", Brazilian Journal of Operations \& Production Management, Vol. 15, No. 2, pp. 173-181, available from: https://bjopm.emnuvens.com.br/bjopm/article/view/335 (access year month day). 